\title{
PENINGKATAN KEMAMPUAN BERPIKIR KRITIS SISWA MELALUI MODEL PEMBELAJARAN KOOPERATIF THINK PAIR SHARE DI KELAS X SMA NEGERI 1 PADANG BOLAK
}

\author{
Ade Isma Hasibuan, Abubakar, Fatma Suryani Harahap \\ Pendidikan Kimia, FKIP Universitas Muhammadiyah Tapanui Selatan \\ Adehasibuan01@gmail.com
}

DOI : 10.31604/ptk.v1i3.202-212

\begin{abstract}
The problem of this research is the low of the student' ability critical thinking and the result of student study of SMA Negeri 1 Padang Bolak in class ten. The goal of this research is to make the critical thinking of the student of the student better and to make better the result of their study is chemistry by using cooperative studying think pair share. The tool to collect the data is a test of ability in critical thinking questioner of critical thinking, the paper of student activity and also teacher work. The observation kind of research is class action research (PTK). The result of the student study by using studying method of student cooperatives think pair share in the class of ten and according to the result of the student ability in critical thinking in the first cycle is 16 the student pass the test and the second cycle about 25 the student pass the test from 30 students follow student test. The result questioner of critical thinking first cycle is enough and the second cycle is very good. The resulting activity observation student has increased as well as the teacher performance observation that has increased. From the research, we know that there is the growth I the questioner of student thinking ability, student activities and the teacher's ability in using think pair share cooperative studying model in class ten of Mia-4 SMA Negeri 1 Padang Bolak. So, this model can be used I chemistry study and others.
\end{abstract}

Keywords: Critical Thinking, Think Pair Share, Chemical Bonds.

\begin{abstract}
Abstrak
Masalah dalam penelitian ini adalah rendahnya kemampuan berpikir kritis siswa dan hasil belajar siswa kelas X SMA Negeri 1 Padang Bolak. Tujuan penelitian ini adalah untuk meningkatkan kemampuan berpikir kritis belajar siswa dan untuk meningkatkan hasil belajar siswa pada pokok bahasan ikatan kimia melalui model pembelajaran kooperatif think pair share. Alat pengumpul data adalah hasil tes belajar, lembar angket kemampuan berpikir kritis, lembar observasi aktivitas siswa dan kinerja guru. Jenis penelitian ini adalah penelitian tindakan kelas (PTK). Hasil tes belajar siswa pada siklus I 16 orang siswa yang tuntas dan siklus II 25 orang siswa yang tuntas dari 30 siswa yang mengikuti tes belajar. Hasil angket kemampuan berpikir kritis pada siklus I dengan kategori cukup dan siklus II dengan kategori sangat baik, hasil observasi aktivitas siswa mengalami peningkatan begitu juga dengan observasi kinerja guru yang mengalami peningkatan. Berdasarkan hasil penelitian dapat disimpulkan bahwa, terdapat peningkatan hasil belajar siswa, angket kemampuan berpikir kritis siswa, aktivitas siswa dan kemampuan guru dalam menerapkan model pembelajaran kooperatif think pair

PeTeKa (Jurnal Penelitian Tindakan Kelas dan Pengembangan Pembelajaran) | 202
\end{abstract}


PeTeKa (Jurnal Penelitian Tindakan Kelas dan Pengembangan Pembelajaran)

Vol 1 No 3 Tahun 2018 Hal 202-212

share di kelas X Mia-4 SMA Negeri 1 Padang Bolak. Untuk itu, model pembelajaran kooperatif think pair share dapat diterapkan pada pembelajaran kimia dan pembelajaran lainnya.

Kata Kunci: Kemampuan Berpikir Kritis, Think Pair Share, Ikatan Kimia.

\section{PENDAHULUAN}

Ikatan kimia adalah sebuah proses fisika yang bertanggung jawab dalam interaksi gaya tarik menarik antara dua atom atau molekul yang bertanggung jawab yang menyebabkan suatu senyawa diatomik atau poliatomik menjadi stabil. hal ini, ditunjukkan dari cara guru dalam memberikan konsep kepada peserta didik.

Guru memberikan konsep secara langsung tanpa mengajak siswa untuk bersama-sama berpikir melalui proses penemuan. Padahal melalui proses penemuan mampu mengembangkan kemampuan berpikir (Ningsih dkk, 2012). Kemampuan berpikir kritis merupakan berpikir secara terarah dan jelas dalam menyelesaikan permasalahan. Kemampuan berpikir kritis, bila menggunakan model pembelajaran yang menarik dan sesuai, guru dapat menyampaikan isi materi dengan mudah dan membiarkan siswa berpikir secara kritis, rasional dan bernalar secara cepat sehingga tidak lagi menggunakan konsep secara langsung (Rahayu dan Stephani, 2015).

Siswa yang memiliki kemampuan berpikir kritis baik tinggi, sedang, dan rendah bisa dilihat dengan cara menggunakan aspek indikator berpikir kritis menurut Ennis (1985), yaitu (1) memberi penjelasan dasar (klarifikasi), (2) membangun keterampilan dasar, (3) menyimpulkan, (4) memberi penjelasan lebih lanjut, dan (5) mengatur strategi dan taktik. Indikator ini, bisa membantu guru untuk melihat kemampuan berpikir kritis siswa.

Untuk meningkatkan kemampuan berpikir kritis siswa, guru harus mampu memilih suatu model pembelajaran dalam melaksanakan proses belajar mengajar. Model pembelajaran adalah suatu perencanaan, atau suatu pola yang digunakan sebagai pedoman dalam merencanakan pembelajaran dalam tutorial dan untuk menentukan perangkat pembelajaran termasuk di dalamnya buku-buku, film, komputer, dan lain-lain.

Oleh karena itu, guru harus memiliki strategi yang sesuai. Salah satunya adalah menerapkan model pembelajaran think pair share (TPS). Model pembelajaran think pair share akan termotivasi siswa untuk selalu mempersiapkan diri bersama dengan kelompoknya dalam memahami setiap meteri pembelajaran di kelas. Selain itu siswa juga dapat mengembangkan kemampuan berpikir kritisnya dengan cara melakukan diskusi dengan teman kelompoknya maupun dari kelompok lain. Untuk bisa melaksanakan diskusi dengan baik, siswa diharapkan menguasai materi yang diajarkan dengan cara banyak membaca sebelum proses pembelajaran berlangsung. Dengan demikian proses pembelajaran akan berjalan dengan baik (Purnomo, 2013). Model pembelajaran jenis think pair share termasuk juga kedalam pembelajaran kooperatif. Adapun ciriciri pembelajaran kooperatif (1) bekerja sama dalam kelompok, (2) kelompok dibentuk dengan berbagai kemampuan tinggi, sedang, dan rendah. (3) anggota 
kelompok berbagai ras, atau budaya yang berbeda. Dan (4) penghargaan lebih beriorentasi pada kelompok daripada individu. (Surianti dkk, 2016).

\section{METODE}

Penelitian ini dilaksanakan di kelas X Mia-4 SMA Negeri 1 padang bolak, waktu penelitian ini dilaksanakan pada tanggal 16 Maret s/d 17 Mei 2018. Subjek dalam penelitian ini adalah siswa kelas X Mia-4 SMA Negeri 1 Padang Bolak yang terdiri dari 30 siswa, terdiri dari 15 siswa laki-laki dan 15 siswa perempuan. Jenis penelitian ini adalah penelitian tindakan kelas (classroom action research) didasarkan atas konsep pokok bahwa penelitian tindakan terdiri dari tempat komponen pokok yaitu: perencanaan/planning, tindakan/ action, pengamatan/ observing, refleksi/ reflecting (Arikunto, 2009).

\section{Perencanaan ( Planning )}

Langkah-langkah

yang

dilakukan dalam tahap perencanaan adalah

a) Pertama, peneliti menvalidasi soal, dimana soal tersebut ada 10 butir soal essay. Kemudian, bertemu guru mata pelajaran kimia dan membicarakan rancangan penelitian yang akan dilaksanakan.

b) Kedua, peneliti menyiapkan silabus dan menyesuaikan silabus dengan guru mata pelajaran.

c) Ketiga, peneliti memberikan RPP untuk disetujui oleh guru mata pelajaran.

d) Keempat, peneliti mengajukan model pembelajaran kooperatif think pair share dan menjelaskan sintaksnya kepada guru untuk merapkan model tersebut dalam proses belajar mengajar. e) Kelima, peneliti telah menyiapkan bahan ajar seperti LKS (lembar kerja siswa), angket beserta instrumen tes.

f) Keenam, peneliti telah menyiapkan alat dokumentasi seperti: laptop, infocus dan buku.

\section{Pelaksanaan ( Action )}

Pelaksanaan dalam penelitian ini meliputi:

a) Peneliti membagikan angket kemampuan berpikir kritis siswa.

b) Guru menjelaskan tujuan pembelajaran.

c) Guru memberikan rangsangan motivasi belajar.

d) Guru memberikan pertanyaan tentang kehidupan sehari-hari dan berkaitan pada materi tersebut.

e) Guru menjelaskan materi ikatan kimia.

f) Guru membagikan kelompok dengan teman sebangkunya. Dimana, dalam satu kelompok terdiri 3 siswa.

g) Guru membagikan LKS (lembar kerja siswa).

h) Siswa akan berdiskusi untuk menjawab LKS yang diberikan guru.

i) Guru memanggil salah satu siswa dari perwakilan kelompokkelompoknya untuk mempersentasikan hasil diskusinya.

j) Guru memberikan kesimpulan mengenai materi tersebut dan meyuruh siswa untuk belajar.

k) Peneliti mengevaluasi siswa.

1) Peneliti membagikan lembar observasi.

\section{Pengamatan (Observation)} meliputi:

Pengamatan dalam penelitian ini

a) Peniliti mengamati situasi kegiatan belajar mengajar dan Keaktifan siswa.

b) Peneliti mengamati kemampuan berpikir kritis siswa pada angket dan instrumen tes yang diberikan. 
PeTeKa (Jurnal Penelitian Tindakan Kelas dan Pengembangan Pembelajaran)

Vol 1 No 3 Tahun 2018 Hal 202-212

c) Peneliti mengamati kinerja guru menggunakan model pembelajaran think pair share keaktifan guru.

\section{Evaluasi dan Refleksi (Reflection)}

Refleksi dilakukan bertujuan untuk mengevaluasi hasil tindakan yang dilakukan yaitu dengan cara melakukan penilaian terhadap proses yang terjadi, masalah yang muncul saat tindakan yang dilakukan. Menilai hasil tindakan dari instrumen tes dan angket yang digunakan. Hasil tersebut tercapai dalam indikator keberhasilan $75 \%$.

\section{HASIL DAN PEMBAHASAN}

\section{Deskripsi Hasil Penelitian}

Berdasarkan hasil tes yang telah dilaksanakan di kelas X MIA 4 di SMA Negeri 1 Padang Bolak Tahun Pelajaran 2017-2018 diperoleh data mengenai kemampuan berpikir kritis kimia siswa sebelum dan sesudah pembelajaran dengan menerapkan model pembelajaran kooperatif think pair share.

\section{Hasil Penelitian Tindakan Kelas Siklus I}

Siklus I merupakan pembelajaran dengan pokok bahasan ikatan kimia dengan model pembelajaran kooperatif think paire share mulai diperkenalkan kepada siswa dalam pembelajaran ini. Siklus I dilaksanakan 2 kali pertemuan. Masingmasing pertemuan 2 jam pelajaran $(2 \mathrm{x}$ 45 menit) kelas X MIA 4 SMA Negeri 1 Padang Bolak Tahun Pelajaran 20172018.

\section{Perencanaan (Planning)}

Kegiatan ini dilaksanakan pada hari Selasa 17 April 2018 pukul 08:00 Wib di sekolah. Pertama, Peneliti bertemu dengan Bapak Kepala Sekolah SMA Negeri 1 Padang Bolak dan menyampaikan tujuan peneliti untuk penelitian di sekolah serta menyerahkan surat penelitian. kemudian, Peneliti bertemu dengan guru mata pelajaran kimia. Peneliti menjelaskan jenis penelitian kepada guru. Peneliti dan guru mendiskusikan rancangan tindakan yang akan dilakukan dalam proses penelitian, dan disepakati bersama. Kemudian, guru mempersilakan untuk melaksanakan penelitian di kelas $\mathrm{X}$ Mia-4 pada hari Rabu 18 April 2018.

\section{SIMPULAN}

$\begin{array}{cc}\text { Dalam } & \begin{array}{c}\text { penelitian } \\ \text { pembelajaran }\end{array} \\ \text { Pelaksanaan } & \text { dengan }\end{array}$ menerapkan model pembelajaran Project based learning pada materi pokok pencemaran lingkungan dalam penelitian ini berjalan dengan baik dan mengalami peningkatan selama pelaksanaan pembelajaran. Hal ini dibuktikan dengan perolehan nilai ratarata total aktivitas guru dalam mengelola pembelajaran pada siklus I masih sebesar 2,8 dengan persentase $70 \%$ atau berada pada kategori cukup. Pada siklus II nilai rata-rata total yang diperoleh meningkat menjadi 3,3 dengan persentase $91 \%$ atau berada pada kategori sangat baik. Untuk hasil yang lebih jelas mengenai peningkatan kadar aktivitas guru dalam mengelola pembelajaran dari siklus I ke siklus II.

\section{Pelaksanaan (Action)}

Pertemuan pertama dilaksanakan pada hari Rabu 18 April 2018 (10.1512.15) selama 2 jam pelajaran $(2 \times 45$ menit) di kelas X Mia-4 SMA Negeri 1 Padang Bolak. Guru bertindak sebagai pemimpin berjalannya proses belajar mengajar dan peneliti bertindak sebagai pengamat dalam mengamati jalannya pembelajaran. Guru memberikan apersepsi berupa motivasi kepada siswa. Guru menjelaskan tujuan pembelajaran. 
Kemudian guru menjelaskan sekilas mengenai materi ikatan kimia yaitu menjelaskan pengertian dan jenis - jenis reaksi ikatan kimia. Guru menyajikan pembelajaran dengan memberikan pertanyaan-pertanyaan berupa minuman pocari sweat, garam dapur serta foto pernikahan mengenai kehidupan sehari-hari dan mengkaitkan dengan materi ikatan kimia. Setelah itu guru membagikan kelompok dinama dalam satu kelompok ada 3 siswa dan menjelaskan kepada siswa bagaimana cara belajar dengan berkelompok yaitu diskusi dan bekerja sama untuk menyelesaikan soal. Guru membagikan LKS kepada siswa yang berisi pertanyaan-pertanyaan mengenai kestabilan unsur, struktur lewis serta ikatan ion dan ikatan kovalen.

$$
\text { Siswa diminta untuk }
$$

mendiskusikan jawaban pertanyaan yang ada dalam LKS dan setiap siswa dituntut untuk memahami materi yang dibahas dalam kelompok itu. selanjutnya siswa disuruh untuk mempersentasekan hasil diskusinya ke depan dan membiarkan kelompok lain untuk menanggapinya.

Pada langkah akhir, guru memberikan kesimpulan dari pembelajaran, dan mempersilahkan siswa untuk bertanya apa yang tidak dimengerti dalam materi ikatan kimia. Pertemuan kedua dilaksanakan pada hari Kamis 19 April 2018 (08.00 10.00) selama 2 jam pelajaran $(2 \times 45$ menit) di kelas X Mia-4 SMA Negeri 1 Padang Bolak. Adapun pelaksanaan tindakan kelas sebagai berikut: guru membuka pelajaran dan mengabsen siswa, jumlah siswa yang hadir 30 orang yaitu semua siswa hadir, guru memberikan apersepsi dengan mengingatkan kembali apa pengertian dan jenis-jenis ikatan kimia dan menjelaskan cara menentukan gambar struktur lewis, katan ion dan ikatan kovalen katan ion. Melihat banyaknya siswa yang tidak mau tau dan hanya membiarkan siswa yang pintar saja yang menjawab guru memberikan soal ikatan ion dan ikatan kovalen di papan tulis dan memacu siswa untuk memperrebutkan soal yang di papan tulis.

Guru memberikan kesempatan kepada siswa untuk menjawab yang ada di papan tulis setelah itu guru memberikan kesempatan kepada siswa untuk menanyakan hal - hal yang belum dimengerti, membimbing siswa untuk membuat rangkuman, guru mengembalikan siswa ke dalam bentuk yang semula kemudian guru memberikan soal tes ikatan kimia dan setelah itu menyuruh siswa mengisi angket yang disediakan oleh peneliti untuk mengetahui kemampuan berpikir kritis siswa dalam penerapan model pembelajaran TPS (think pair share). Berhubung waktu pelajaran telah selesai kemudian guru mengakhiri pelajaran. Dan yang terakhir guru memberikan penilaiannya terhadap observasi aktivitas belajar kimia siswa.

\section{Observasi}

1. Hasil Observasi Aktivitas Siswa Siklus I

Pengamatan atau observasi merupakan bagian dari proses dari pengumpulan data yang diperlukan dalam penelitian. Guru yang bertindak sebagai observasi mengenai siswa yang sedang mengikuti proses belajar dikelas pada materi ikatan kimia dengan model pembelajaran TPS untuk meningkatkan hasil tes kemampuan berpikir kritis siswa. Hasil pengamatan terhadap aktivitas siswa dalam pembelajaran setiap pertemuan, hasil tersebut disajikan secara ringkas. Perolehan persentase observasi aktivitas siswa siklus I adalah 44,93\% sedangkan untuk klasifikasi nilai adalah cukup. Dari hasil 
PeTeKa (Jurnal Penelitian Tindakan Kelas dan Pengembangan Pembelajaran)

Vol 1 No 3 Tahun 2018 Hal 202-212

observasi aktivitas siswa belum sesuai dengan apa yang direncanakan dalam penelitian ini dan belum memenuhi indikator keberhasilan yang ditetapkan adalah $\geq 75 \%$. Karena, kurangya siswa menunjukkan respon pada pelajaran, kurangnya siswa dalam berpikir kreatif, kurangnya siswa aktif berdiskusi dan kuranngya kemampuan siswa dalam mempersentasikan hasil diskusi.

2. Hasil Observasi Guru Dalam Proses Belajar Mengajar

Pengamatan atau observasi merupakan bagian dari proses dari pengumpulan data yang diperlakukan dalam penelitian. Observator yang akan menilai sejauh mana kemampuan guru dalam mengelola kelas pada pokok bahasan ikatan kimia dengan model pembelajaran kooperatif think pair share untuk meningkatkan kemampuan berpikir kritis kimia siswa. Hasil observasi kinerja guru dalam proses belajar mengajar pada siklus I adalah $63,34 \%$. Hasil observasi aktivitas guru dalam proses belajar mengajar pada siklus pertama masih tergolong rendah. Berdasarkan uraian-uraian di atas, terlihat bahwa aktivitas guru belum terpenuhi dengan baik. Kriteria yang didapat masih sangat cukup, siswa belum terbiasa dengan model pembelajaran think pair share, sehingga perlu tindak lanjut pada siklus II dengan upaya lebih baik lagi, agar siswa aktivitas siswa dan guru meningkat minimal kategori baik yaitu $\geq 75 \%$.

\section{Hasil Evaluasi Dan Refleksi Siklus I}

\section{Hasil Evaluasi Siklus I}

Berdasarkan hasil evaluasi siklus I, penilaian terhadap tes hasil belajar siswa pada siklus I dan hasilnya masih pada kategori "cukup" dengan persentasi sebesar 53,33\% yang tuntas, untuk itu perlu adanya perbaikan dan peningkatan pembelajaran siklus II.
Diharapkan pada siklus kedua hasil yang diperoleh lebih baik lagi dibandingkan dengan siklus I. Untuk itu guru PTK bersama peneliti merancang kegiatan yang lebih baik lagi agar memperoleh hasil yang baik sesuai dengan kriteria ketuntasan minimal (KKM) yang telah ditetapkan sekolah yaitu nilai di atas 70 dan keseluruhan siswa tuntas $\geq 75 \%$. Berdasarkan hasil angket kemampuan berpikir kritis siswa, dengan persentase $63,44 \%$ dan masih berada pada kriteria cukup. Dimana, kategori kurang ada 5 siswa, kategori cukup ada 13 orang dan kategori baik ada 12 orang.

\section{Refleksi Siklus I}

Pada tindakan siklus I ini penerapan model pembelajaran think pair share pada pokok bahasan ikatan kimia belum berhasil sesuai keinginan. Analisis terhadap observasi bahan untuk menetukan tindakan selanjutnya. Rendahnya tingkat tes kemampuan berpikir kritis siswa mungkin dikarenakan oleh beberapa hal. Setelah diadakan refleksi antara guru, observer dan peneliti maka diperoleh :

1) kelebihan

a) Beberapa siswa senang dengan cara belajar berkelompok. Karena, bisa kerja sama.

b) Beberapa siswa mulai berani memberikan tanggapan dari pertanyaan yang diajukan guru. Ini dapat dijadikan sebagai pemicu kemampuan berpikir kritis siswa dalam belajar.

2) kekurangan

a) Karena proses belajarnya dalam bentuk kelompok. Maka, pengelolaan kelas belum baik sehingga siswa banyak yang ribut saat diskusi berlangsung.

b) Guru belum maksimal dalam menggunakan model 
Ade Isma Hasibuan, dkk. Peningkatan Kemampuan Berpikir Kritis Siswa ...

pembelajaran kooperatif think pair share.

c) Kemampuan berpikir kritis siswa dalam belajar kimia masih dikategorikan rendah.

d) Hasil belajar siswa masih dikategorikan kurang.

Beberapa yang harus diperbaiki pada siklus selanjutnya adalah sebagai berikut :

1. Guru memperbaiki dalam penyampaian materi dengan cara membuat siswa untuk menggali kemampuan berpikir kritis dalam belajar. Dan membiarkan siswa untuk memberikan tanggapan atas hasil berpikirnya tersebut.

2. Guru harus menggunakan waktu secara efektif

\section{Hasil Penelitian Siklus II}

\section{Perencanaan (Planning)}

Tindakan siklus II pada pertemuan pertama dilaksanakan pada 21 April 2018 pukul $(11.00-12.30)$ di kelas X Mia-4. Pada kesempatan tersebut peneliti belajar dari kesalahan dan berusaha memperbaiki kesalahan dari siklus I adapun perencanaan untuk memperbaiki siklus I yaitu : Guru harus bersikap tegas pada siswa yang kurang peduli dan kurang mendengarkan guru saat menjelaskan pembelajaran begitu juga penggunaan waktu harus disesuaikan guru harus menjelaskan materi ikatan kimia dengan benar sesuai model think pair share menggunakan lembar kerja siswa dengan cara menggali pengetahuan siswa dan memberikan siswa mengemukakan pendapat tentang materi ikatan kimia. Begitu juga dengan memberikan kesempatan siswa untuk bertanya tentang hal yang belum dimengerti dan begitu juga guru bertanya balik kepada siswa agar meningkatkan kemampuan berpikir kritis kimia siswa. Setelah beberapa siswa menanggapi pertanyaan dan guru meluruskan jawaban diberikan siswa guru membimbing siswa membuat kesimpulan.

\section{Pelaksanaan (Action)}

Tindakan kedua pertemuan pertama dilaksanakan pada hari Sabtu 21 April 2018 (08.00 - 10.00). Guru bertindak sebagai pemimpin berjalannya pembealajaran dan peneliti bertindak sebagai pengamat untuk mengamati jalannya proses belajar mengajar, guru memberikan tes kemampuan berpikir kritis kimia siswa. Guru memulai pembelajaran dengan mengucapkan salam, kemudian mengabsen siswa dan mengingatkan siswa pada materi yang lewat tentang materi ikatan kimia. Setelah itu guru kembali melanjutkan pembelajaran yaitu menjelaskan materi ikatan kimia. Guru menyajikan informasi kepada siswa dan menyediakan tugas untuk kelompok. Kemudian siswa membagikan kelompok dimana dalam satu kelompok terdapat 3 siswa. Kemudian, guru membagikan LKS kepada siswa yang berisi pertanyaanpertanyaan mengenai kestabilan unsur, struktur lewis serta ikatan ion dan ikatan kovalen.seterusnya guru membimbing siswa yang belum mengerti dan mengarahkan siswa untuk berdiskusi dan mempersentasikan hasil diskusinya di depan kelas. Dan memberikan kesempatan kelompok lain untuk bertanya dan mengemukakan pendapatnya dan guru meluruskan jawaban siswa yang mengemukakan pendapatnya. setelah itu, menyuruh siswa mengisi angket yang disediakan oleh peneliti untuk mengetahui kemampuan berpikir kritis siswa dalam penerapan model pembelajaran TPS (think pair share).

Tindakan kedua pada pertemuan ke-dua siklus II dilaksanakan pada 
PeTeKa (Jurnal Penelitian Tindakan Kelas dan Pengembangan Pembelajaran)

Vol 1 No 3 Tahun 2018 Hal 202-212

tanggal 23 Mei 2018 hari Senin (10.00 - 11.00). Selama 2 jam mata pelajaran (2 x 45 menit) di kelas X Mia-4 SMA Negeri 1 Padang Bolak. Adapun pelaksanaan tindakan kelas sebagai berikut: guru membuka pelajaran dan mengabsen siswa, jumlah siswa yang hadir 30 orang yaitu semua siswa hadir, guru memberikan apersepsi dengan mengingatkan kembali apa pengertian dan jenis-jenis ikatan kimia dan menjelaskan cara menentukan gambar struktur lewis, katan ion dan ikatan kovalen katan ion. Melihat banyaknya siswa yang tidak mau tau dan hanya membiarkan siswa yang pintar saja yang menjawab guru memberikan soal ikatan ion dan ikatan kovalen.

Guru memberikan tugas kepada masing-masing kelompok, guru mengembalikan siswa ke dalam bentuk yang semula kemudian guru memberikan soal tes ikatan kimia dan setelah itu menyuruh siswa mengisi angket yang disediakan oleh peneliti untuk mengetahui kemampuan berpikir kritis siswa dalam penerapan model pembelajaran TPS (think pair share). Waktu pelajaran telah selesai kemudian guru mengakhiri pelajaran. Dan yang terakhir guru memberikan penilaiannya terhadap observasi aktivitas belajar kimia siswa.

\section{Observasi}

1. Hasil Observasi Aktivitas Siswa Siklus II

Pengamatan atau observasi merupakan bagian dari proses pengumpulan data yang diperlukan dalam penelitian. Guru yang bertindak sebagi observer dan siswa sedang mengikuti proses belajar di kelas. Berdasarkan hasil observasi aktivitas siswa siklus II dapat dijelaskan bahwa perolehan skor dan persentase yang didapat di siklus II telah memenuhi kategori sebesar 81,16\%, sedangkan untuk kualifikasi nilainya adalah sangat baik. Dari hasil observasi aktivitas siswa siklus II bahwa hasil observasi aktivitas siswa telah memenuhi indikator keberhasilan yang direncanakan dalam penelitian sebesar $75 \%$, penelitian ini tidak perlu dilanjutkan dan berhenti pada siklus II.

2. Hasil Obseravsi Guru Dalam Proses Belajar Mengajar

Pengamatan atau observasi merupakan bagian dari proses dari pengumpulan data yang diperlakukan dalam penelitian. Observator yang akan menilai sejauh mana kemampuan guru dalam mengelola kelas pada pokok bahasan ikatan kimia dengan model pembelajaran kooperatif think pair share untuk meningkatkan kemampuan berpikir kritis kimia siswa. Hasil observasi aktivitas guru dalam proses belajar mengajar pada siklus kedua meningkat yaitu $95,00 \%$ dengan kualifikasi nilai sangat baik. Hal ini berarti mengalami perbaikan dari siklus pertama. Pada siklus kedua ini guru lebih aktif dalam menerapkan model pembelajaran kooperatif think pair share dibandingkan siklus yang pertama. Maka, hasil yang ditunjukkan telah mencapai indikator yang ditetapkan dan penelitian ini diberhentikan pada siklus II.

\section{Hasil Evaluasi Dan Refleksi Siklus II}

\section{Hasil Evaluasi II}

Berdasarkan hasil evaluasi siklus II, penilaian terhadap hasil tes belajar siswa pada siklus II ada peningkatan dari siklus II dengan perolehan persentase $83,33 \%$ kategori sangat baik dan telah memenuhi indikator keberhasilan yang ditetapkan sebesar $75 \%$ dengan kriteria ketuntasan minimal (KKM) 70, siklus II telah memenuhi kriteria ketuntasan yang ratarata diperoleh sebesar. Dilihat dari hasil 
Ade Isma Hasibuan, dkk. Peningkatan Kemampuan Berpikir Kritis Siswa ...

tes siswa siklus II tersebut bahwa persentase ketuntasan telah memenuhi indikator keberhasilan, maka penelitian ini diberhentikan pada siklus II. Berdasarkan tabel diatas, hasil angket kemampuan berpikir kritis siswa telah meningkat dengan perolehan persentase $82,38 \%$ dengan kriteria sangat baik. Dan sudah memenuhi indikator keberhasilan siswa diatas $75 \%$.

\section{Refleksi siklus II}

Adapun keberhasilan yang dicapai pada siklus II adalah sebagai berikut :

1) kelebihan

a) Guru berhasil meningkatkan aktivitas belajar siswa berupa soal yang diberikan. Di siklus kedua telah dapat diatasi dengan baik terbukti dari hasil observasi kinerja guru mencapai 95,00\% dengan kualifikasi sangat baik.

b) Aktivitas belajar siswa juga meningkat karena siswa telah mengemukakan pendapat dan berani mengajukan pertanyaan dari soal yang diberikan guru terbukti dari hasil observasi siswa mecapai nilai $81,16 \%$ dengan kualifikasi sangat baik.

c) Kemampuan berpikir kritis siswa dalam belajar juga meningkat. Dikarenakan, berani menaggapi materi dan mampu menguraikan sesuatu secara terperinci terbukti dari hasil bahwa 82,38\% dengan kualifikasi baik.

d) Hasil belajar siswa meningkat pada materi ikatan kimia. Karena, memenuhi indikator keberhasilan siswa. Hal ini terbukti dari ratarata pencapaian 53,33 menjadi $83,33 \%$.
2) Kekurangan

Masih ada 5 siswa yang belum tuntas dalam belajar materi ikatan kimia.

Menurut Agus Purnomo (2013), dari hasil penelitian tersebut bahwa keterampilan berpikir kritis siswa mengalami peningkatan, pada siklus I yaitu $64,16 \%$, pada siklus II $83,78 \%$ sedangkan pada siklus III 94,59\%. Hasil angket respon siswa pada siklus I yaitu $88,1 \%$, pada siklus II sebesar $91,35 \%$, dan pada siklus III meningkat menjadi 92,16\%. Dapat disimpulkan bahwa penggunaan model pembelajaran kooperatif tipe TPS dapat meningkatkan kemampuan berpikir kritis siswa pada mata pelajaran IPS kelas IV SDN Jeruk I/469 Surabaya.

Begitu juga dengan penelitian ini berakhir setelah pelaksanaan siklus II, karena telah mencapai indikator keberhasilan yang telah ditetapkan sebesar $\geq 75 \%$. Dalam penelitian yang saya laksanakan, terjadi peningkatan kemampuan berpikir kritis setelah diberi tindakan kelas berupa penerapan model pembelajaran kooperatif think pair share menggunakan angket. Pada siklus pertama dengan persentase 63,44\% dengan kualifikasi nilai cukup dan disiklus kedua meningkat menjadi $82,38 \%$ dengan kualifikasi sangat baik.

Tabel 1: Peningkatan Kemampuan Berpikir Kritis Siswa

\begin{tabular}{rrc}
\hline Siklus I & Siklus II & Peningkatan \\
\hline $63,44 \%$ & $82,38 \%$ & $18,94 \%$ \\
\hline
\end{tabular}


PeTeKa (Jurnal Penelitian Tindakan Kelas dan Pengembangan Pembelajaran)

Vol 1 No 3 Tahun 2018 Hal 202-212

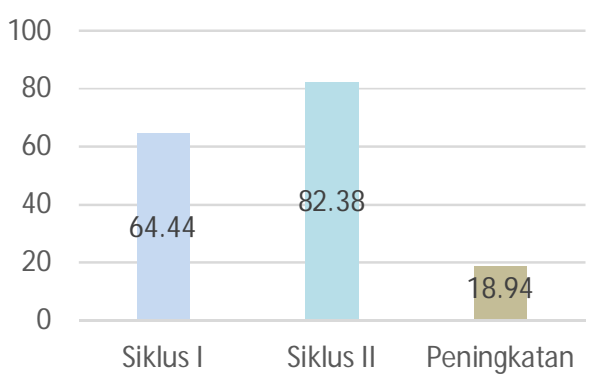

Gambar 1: Persentase Ketuntasan Tes Hasil Belajar

Dan hasil belajar siswa juga meningkat dimana pada siklus pertama 16 siswa yang tuntas dengan nilai ratarata 67,27 dengan persentase $53,33 \%$ sedangkan siklus kedua 25 siswa yang tuntas dengan nilai rata-rata 76,08 dan persentasenya bernilai $83,33 \%$.

Tabel 2: Peningkatan Tes Hasil Belajar

\begin{tabular}{ccc}
\hline Siklus I & Siklus II & Peningkatan \\
\hline $53,33 \%$ & $83,33 \%$ & $30 \%$ \\
\hline
\end{tabular}

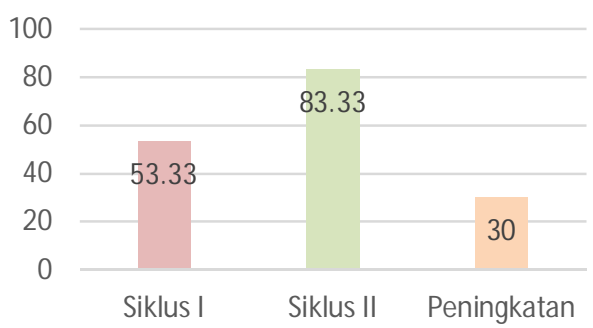

Gambar 2: Persentase Ketuntasan Tes Hasil Belajar

\begin{tabular}{rrrr}
\multicolumn{2}{c}{ Persentase } & hasil observasi \\
aktivitas & siswa & ditinjau & dalam
\end{tabular} kemampuan berpikir kritis siswa meningkat dimana siklus pertama $71,00 \%$ menjadi $81,16 \%$ di siklus kedua dengan peningkatan $10,16 \%$ dengan kualifikasi nilai sangat baik.

Tabel 3: Peningkatan Observasi Aktivitas Siswa

\begin{tabular}{ccc}
\hline Siklus I & Siklus II & Peningkatan \\
\hline $71,00 \%$ & $81,16 \%$ & $10,16 \%$ \\
\hline
\end{tabular}

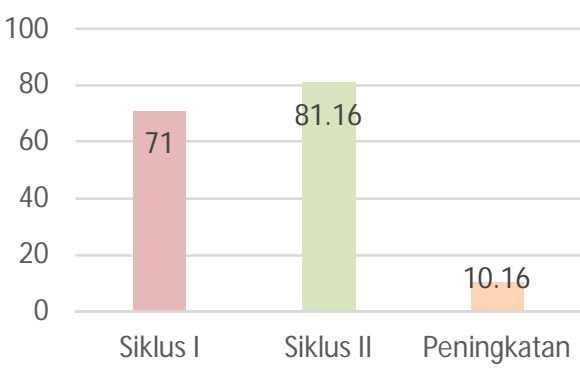

Gambar 3: Persentase Ketuntasan Tes Hasil Belajar

Dan hasil observasi kinerja guru dalam menerapkan kooperatif think pair share juga meningkat pada siklus pertama $63,34 \%$ menjadi $95,00 \%$ di siklus kedua dengan peningkatan $31,66 \%$ dengan kualifikasi nilai sangat baik.

Tabel 4: Peningkatan Observasi Aktivitas Siswa

\begin{tabular}{ccc}
\hline Siklus I & Siklus II & Peningkatan \\
\hline $63,34 \%$ & $95,00 \%$ & $31,66 \%$ \\
\hline
\end{tabular}

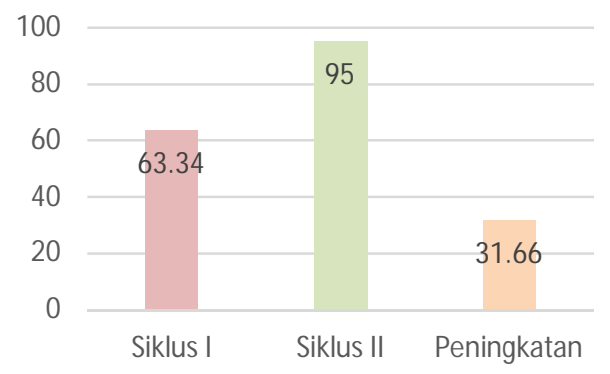

Gambar 4: Persentase Ketuntasan Tes Hasil Belajar

Berdasarkan hasil penelitian "Kemampuan Berpikir Kritis Kimia Siswa Dengan Penerapan Model Pembelajaran Kooperatif Think Pair Share" telah mengalami peningkatan, dapat dilihat pada tabel dan grafik dibawah ini: 
Ade Isma Hasibuan, dkk. Peningkatan Kemampuan Berpikir Kritis Siswa ...

SIMPULAN

Kemampuan berpikir kritis siswa melalui model pembelajaran think pair share (TPS) di kelas X menunjukkan bahwa, hasilnya meningkat. Dikarenakan, telah memenuhi indikator keberhasilan siswa. Dilihat dari siklus pertama dengan persentase $63,44 \%$ dan siklus kedua meningkat dengan persentase sebesar $82,38 \%$ dan sudah dikategorikan sangat baik. Hasil belajar siswa menggunakan model think pair share (TPS) pada materi ikatan kimia telah meningkat. Bahwa siklus pertama belum mencapai indikator keberhasilan siswa dengan perolehan persentase $53,33 \%$ dan siswa yang tuntas berjumlah 16 orang. Setelah tindakan selanjutnya, di siklus kedua meningkat dengan persentase $83,33 \%$ dan sudah mencapai indikator keberhasilan siswa, untuk siswa yang tuntas berjumlah 25 orang dan sudah dikategorikan sangat baik.

\section{DAFTAR PUSTAKA}

Arikunto, S. 2009. Dasar-Dasar Evaluasi Pendidikan. Jakarta: PT Rineka Cipta.

Ennis, R. H. 1985. A Logical Basis For Measuring Critical Thinking Skills. Educational Leadership 43(2).
Ningsih, S. M., Bambang S., \& A. Sopyan. 2012. Implementasi Model Pembelajaran Process Oriented Guided Inquiry Learning (POGIL) Untuk Meningkatkan Kemampuan Berpikir Kritis Peserta didik. Unnes Physics Education Journal 1(2).

Purnomo, Agus. 2014. Peningkatan Kemampuan Berpikir Kritis Siswa Dengan Penerapan Model Pembelajaran Kooperatif Tipe Tps (Think Pair Share) Dalam Pembelajaran IPS Di Sekolah Dasar. Jurnal PGSD 2(1).

Rahayu, D. P., \& Stephani D. P. 2015. Pengaruh Model Pembelajaran Process Oriented Guided Inquiry Learning Terhadap Kemampuan Berpikir Kritispeserta Didik Pada Materi Perubahan Benda.Unnes Science Education Journal 4 (3).

Surianti, N., Yusrizal., \& Saiful. 2016. Penerapan Model Tps Untuk Meningkatkan Keterampilan Berpikir Kritis Dan Pemahaman Konsep Kelarutan Dan Hasil Kali Kelarutan Siswa SMAN 1 Kluet Utara. Jurnal Pendidikan Sains Indonesia 4(2). 